УДК 330.658

DOI: https://doi.org/10.37320/2415-3583/8.14

Бірюков С.I.

асистент кафедри менеджменту та публічного адміністрування, ПВНЗ «Міжнародний науково-технічний університет імені академіка Юрія Бугая»

\title{
ІНСТИТУЦІОНАЛЬНІ ЗАСАДИ ФУНКЦІОНУВАННЯ ПІДПРИСМСТВ ЕЛЕКТРОЕНЕРГЕТИКИ В СУЧАСНИХ ІНТЕГРАЦІЙНИХ РЕАЛІЯХ
}

\begin{abstract}
У статті визначено інституціональні засади функиіонування підприємств електроенергетики в сучасних інтеграційних реаліях. Встановлено, щуо, відповідно до класифікації видів економічної діяльності, підприємства електроенергетики належать до секиії D «постачання електроенергіï, газу, пари та кондиційованого повітря». Цей вид економічної діяльності включає різні групи, серед яких слід назвати групу «виробництво, передача та розподілення електроенергї̈». Ця група підприємств об'єднує такі класи за класифікацією видів економічної діяльності, як виробництво електроенергї, передача електроенергї, розподілення електроенергї та торгівля електроенергією. Діяльність підприємств електроенергетики безпосередньо пов'язана з електроенергетичною системою, частиною якої вона є. Обгрунтовано, ш⿻ у дефініційному значенні синонімічними $є$ поняття «енергетичне господарство», "єдина енергетична система», «енергосистема начіонального господарства», «енергетичний комплекс», які застосовуються в енергетиці у значенні системної єдності виробниитва, перетворення, транспортування, передачі різних видів енергії, їх розподілення, збуту та споживання. Встановлено, щзо об'єднує окреслені поняття застосування теорії систем щодо енергетики. Функиіонування підприємств електроенергетики багато в чому залежить від управління енергетичною системою на державному рівні, щз поєднує державне регулювання та ринкові механізми, включає механізми регулювання природних монополій, тарифної політики відповідно до принцииів реалізації суспільних інтересів. Встановлено, щчо підвишення ефективності функиіонування енергетичної системи є можсливи тільки за умов досягнення консенсусу між усіма його учасниками, дотримання балансу інтересів між виробниками та споживачами електроенергії. Обтрунтовано, щзо функиіонування енергетичних підприємств багато в чому залежить від створених інституціональних умов розвитку всієї енергетичної системи держави, щчо поєднує державне регулювання та ринкові механізми, включає механізми регулювання природних монополій, тарифної політики відповідно до принципів реалізації суспільних інтересів.
\end{abstract}

Ключові слова: функиіонування, підприємства електроенергетики, системний підхід, управління енергетичною системою, інституціональні умови розвитку підприємств.

Постановка проблеми. Умови функціонування підприємств електроенергетики пов'язані перш за все з обмеженістю ресурсів. Це обмеженість природних невідновлюваних ресурсів, що використовуються для виробництва електроенергії, фінансових ресурсів на модернізацію підприємств та енергетичної сфери загалом. Сучасні виклики глобалізаційного розвитку диктують певні вимоги до функціонування підприємств електроенергетики щодо безпечності, екологічності та техногенності їх діяльності, використання наявного природного потенціалу, гармонізації забезпечення економічної ефективності та соціальної спрямованості.

Аналіз останніх досліджень i публікацій. Проблематика здійснення господарської діяльності підприємствами електроенергетики, аналізу ринку електроенергії України та інструментарію його регулювання порушується у великій кількості досліджень вітчизняних науковців. Так, цим питанням присвятили свої роботи О. Битяк, І. Будзко, М. Бурбело, О. Бурляй, Д. Волошин, О. Губрієнко, І. Гусєва, В. Дергачова, В. Євдокімов, Ю. Желєзко, М. Земляний, Н. Кузьминчук, Е. Оборіна, Б. Папков, В. Саприкін, Б. Слупський, В. Точилін, В. Христі- ановський, В Цаплін, Н. Цивенкова, А. Шевцов, В. Шведун та інші науковці.

Проте низка питань у дослідженні функціонування підприємств електроенергетики в умовах обмеженості ресурсів залишаються невирішеними, зокрема інституціональні засади адаптації вітчизняних підприємств електроенергетики до сучасних інтеграційних реалій, модернізаційні аспекти їх функціонування в умовах диверсифікації ресурсних джерел виробництва електроенергії, підвищення ефективності використання ресурсного потенціалу підприємств електроенергетики.

Мета статті полягає у визначенні інституціональних засад функціонування підприємств електроенергетики в сучасних інтеграційних реаліях. Для досягнення поставленої мети у роботі було визначено, до якої категорії за класифікатором КВЕД належать підприємства електроенергетики, які саме підприємства відносять до цієї групи; за використанням системного підходу обгрунтовано залежність функціонування підприємств електроенергетики від енергетичної системи; визначено засади управління енергетичною системою.

Виклад основного матеріалу. Відповідно до класифікації КВЕД [1] підприємства електроенер- 
гетики належать до секції D «постачання електроенергії, газу, пари та кондиційованого повітря». Цей вид економічної діяльності включає різні групи, серед яких слід назвати групу «виробництво, передача та розподілення електроенергії». Ця група підприємств об'єднує такі класи за КВЕД, як виробництво електроенергії, передача електроенергії, розподілення електроенергії та торгівля електроенергією (рис. 1). Необхідно наголосити на тому, що коли говорять про підприємства електроенергетики, то зазвичай кажуть про виробництво, передачу та розподілення електроенергії, але не наголошують на торгівлі електроенергією. При цьому потрібно наголосити на тому, що до групи таких підприємств належать також ті, що контролюють подачу електроенергії, організують іiі постачання, а також займаються ii торгівлею.

Діяльність підприємств електроенергетики безпосередньо пов'язана 3 електроенергетичною системою, частиною якої вона $\epsilon$. Вона мала тривалий процес формування відповідно до зростання темпів споживання електроенергії, географічноприродних особливостей, розвитку інфраструк- тури, науково-технічного прогресу, особливостей розвитку промисловості та національної економіки загалом тощо.

Необхідно зазначити, що енергетичний комплекс визначають якпевну сукупність взаємозв'язків та процесів, що сприяє процесам, пов'язаним 3 усіма видами трансформації енергії від енергетичних ресурсів до ії споживачів, а також описує ïx. Таким чином, незважаючи на різні точки зору науковців щодо особливих нюансів, зазвичай у дефініційному значенні синонімічними є поняття «енергетичне господарство», «єдина енергетична система», «енергосистема національного господарства», «енергетичний комплекс». Ці поняття застосовуються в енергетиці у значенні системної єдності виробництва, перетворення, транспортування, передачі різних видів енергії, їх розподілення, збуту та споживання.

Головним, що об'єднує ці поняття, є застосування теорії систем щодо енергетики. Саме системний підхід дає можливість підвищити енергоефективність національного господарства загалом за рахунок модернізації системи та ії складових частин, оновлення основних засобів, введення

\begin{tabular}{|c|c|}
\hline & $\begin{array}{c}\text { Секція D за КВЕД «Постачання електроенергї̈, газу, } \\
\text { пари та кондиційованого повітря» }\end{array}$ \\
\hline \multicolumn{2}{|r|}{ Груип: Постачання пари, гарячої води та кондиційованого повітря } \\
\hline \multicolumn{2}{|r|}{$\begin{array}{l}\text { Група: Виробництво газу; розподілення газоподібного палива через місцеві } \\
\text { (локальні) трубопроводи }\end{array}$} \\
\hline \multicolumn{2}{|r|}{ Груй: Виробництво, передача та розподілення електроенергії } \\
\hline & $\begin{array}{l}\text { Клас: виробництво електроенергї (експлуатація генеруючих систем із } \\
\text { виробництва електроенергії, зокрема теплових, ядерних, гідроелектричних і } \\
\text { газових турбін, дизельних станцій чи інших поновлюваних джерел) }\end{array}$ \\
\hline \multirow[t]{2}{*}{ 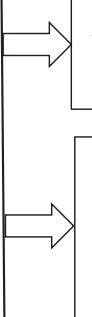 } & $\begin{array}{l}\text { Клас: передача електроенергї (експлуатація систем передачі електроенергії } \\
\text { від місця виробництва до пунктів розподілення) }\end{array}$ \\
\hline & $\begin{array}{l}\text { Клас: розподілення електроенергії (експлуатація розподільчих систем } \\
\text { (включають лінії електропередач, опори ліній електропередач, вимірювальні } \\
\text { прилади та кабелі), які доставляють електроенергію від розподільчих систем } \\
\text { до кінцевого споживача) }\end{array}$ \\
\hline$\Rightarrow$ & $\begin{array}{l}\text { Клас: торгівля електроенергією (продаж електроенергії споживачам; } \\
\text { діяльність посередників або представників, які організовують постачання } \\
\text { електроенергії через мережі електропередач, що експлуатують інші особи; } \\
\text { контроль подачі електроенергії та пропускної здатності) }\end{array}$ \\
\hline
\end{tabular}

Рис. 1. Види підприсмств електроенергетики за КВЕД 
інноваційних процесів управління системою, цілеспрямованої діяльності енергетичних підприємств, підвищення культури енергоспоживання та енергозбереження, задіяння ефективної системи продажу, купівлі та розрахунків тощо.

Системний підхід дає можливість органічно поєднати технологічні можливості та економічні потреби в процесі розвитку національного господарства. Національна електроенергетика вибудовувалася як система в процесі індустріалізації економіки та була теорією великих систем енергетики, що супроводжувалося будуванням iii складних, енергоефективних елементів шляхом поєднання таких процесів, як концентрація, комбінування, централізація, розподілення, транспортування.

Енергетична система $є$ найважливішою системою національної економіки, оскільки без ㄲï безперебійного, чіткого та ефективного функціонування неможливе відтворення суспільного розвитку, а також неможливо забезпечити економічну безпеку розвитку держави. Розвиток економіки, підвищення якості життя населення неможливі без надійного, стабільного та якісного забезпечення електропостачання.

Ефективність функціонування енергетичної системи загалом та енергетичних підприємств зокрема значною мірою визначає конкурентоспроможність національної економіки та досягнення пріоритетів сталого розвитку. Функціональна особливість електроенергетичної сфери полягає у життєзабезпеченні всіх галузей національної економіки та впливі на розміщення й розвиток продуктивних сил, що пов'язано 3 прив'язкою великих споживачів електроенергії до їі виробників.

Енергетична система побудована та функціонує відповідно до теорії систем із притаманними властивостями системи, зокрема $[10 ; 11]$ :

- відкритістю;

- цілісністю;

- ієрархічністю;

- поліструктурністю;

- відтворюваністю;

- самоорганізацією;

- нестійкістю;

- нерівномірністю.

Функціонування енергетичних підприємств багато в чому залежить від управління енергетичною системою на державному рівні, що поєднує державне регулювання та ринкові механізми, включає механізми регулювання природних монополій, тарифної політики відповідно до принципів реалізації суспільних інтересів. Управління енергетичною системою спирається не те, що:

- для розвитку енергетичної системи та узгодження дій ïi суб’єктів необхідна наявність координуючого центру для визначення напрямів розвитку та стратегічних пріоритетів;
- досягнення поставлених стратегічних цілей та поточних завдань зумовлює необхідність окреслення системних пріоритетів у функціоналах локальних суб'єктів управління, якими можуть виступати регіони, муніципалітети, об'єднані територіальні громади, енергетичні компанії тощо;

- для підвищення ефективності управління та прийняття швидких рішень за виникнення певних загроз розвитку єдиної енергетичної системи більш ефективними $є$ використання обмежених ресурсів, задіяння системи аналітичного моніторингу та інформування суб'єктів управління для прийняття оперативних рішень;

- забезпечення щільності взаємодій усіх суб'єктів управління необхідне для підвищення результативності управлінських рішень та ефективності енергетичної системи загалом.

Окреслені особливості єдиної енергетичної системи, вплив глобальних та геополітичних тенденцій зумовлюють ускладнення управління електроенергетикою, зокрема підприємствами електроенергетики.

Керуючим документом щодо управління розвитком національної енергетики в Україні є Розпорядження Кабінету Міністрів України «Про схвалення Енергетичної стратегії України на період до 2035 року «Безпека, енергоефективність, конкурентоспроможність»» [9]. Цю стратегію у 2017 році було прийнято на заміну Енергетичної стратегії України на період до 2030 року, яку було ухвалено у 2013 році.

Основні принципи діяльності підприємств електроенергетики та всього паливно-електроенергетичного комплексу визначено в різних законодавчих та нормативно-правових актах, до яких належать Закони України «Про ринок електричної енергії» [8], «Про природні монополії» [7], «Про Національну комісію, що здійснює державне регулювання у сферах енергетики та комунальних послуг» [4], «Про особливості доступу до інформації у сферах постачання електричної енергіі, природного газу, теплопостачання, централізованого постачання гарячої води, централізованого питного водопостачання та водовідведення» [6] тощо.

Також діяльність підприємств електроенергетики регулюється Постановами Кабінету Міністрів України «Про невідкладні заходи щодо стабілізації фінансового становища підприємств електроенергетичної галузі» [5], «Про затвердження Правил охорони електричних мереж» [3], «Про затвердження Порядку застосування санкцій за порушення законодавства про електроенергетику» [2] тощо.

Постанови Національної комісії, що здійснює державне регулювання у сферах енергетики та комунальних послуг: 
Висновки. Отже, наведений далеко не повний перелік нормативно-законодавчих актів регулювання діяльності підприємств електроенергетики характеризує особливості їх функціонування та регулюючого впливу на їх розвиток. Це також підкреслює значимість функціонування підприємств електроенергетики для убезпечення економічної безпеки національної економіки та ії суб'єктів.

Встановлено, що підвищення ефективності функціонування енергетичної системи $є$ можливим тільки за умов досягнення консенсусу між усіма його учасниками, дотримання балансу інтересів між виробниками та споживачами елек- троенергії. Обгрунтовано, що функціонування енергетичних підприємств багато в чому залежить від створених інституціональних умов розвитку всієї енергетичної системи держави, що поєднує державне регулювання та ринкові механізми, включає механізми регулювання природних монополій, тарифної політики відповідно до принципів реалізації суспільних інтересів.

Подальших наукових розвідок вимагають питання визначення особливостей функціонування підприємств електроенергетики за умов змін моделі ринку електроенергетики для розроблення заходів щодо підвищення ефективності їх діяльності.

\section{Список використаних джерел:}

1. Класифікація видів економічної діяльності (КВЕД - 2010). URL: http://kved.ukrstat.gov.ua/KVED2010/kv10_i.html (дата звернення: 18.02.2019).

2. Про затвердження Порядку застосування санкцій за порушення законодавства про електроенергетику : Постанова Кабінету Міністрів України від 19 липня 2000 року № 1139.

3. Про затвердження Правил охорони електричних мереж : Постанова Кабінету Міністрів України від 4 березня 1997 року № 209.

4. Про Національну комісію, що здійснює державне регулювання у сферах енергетики та комунальних послуг : Закон України від 13 червня 2019 року № 1540-VIII.

5. Про невідкладні заходи щодо стабілізації фінансового становища підприємств електроенергетичної галузі : Постанова Кабінету Міністрів України від 24 березня 1999 року № 441.

6. Про особливості доступу до інформації у сферах постачання електричної енергії, природного газу, теплопостачання, централізованого постачання гарячої води, централізованого питного водопостачання та водовідведення : Закон України від 10 грудня 2015 року № 887-VII.

7. Про природні монополії : Закон України № 1682-III, редакція від 20 квітня 2000 року.

8. Про ринок електричної енергії : Закон України від 24 вересня 2019 року № 2019-VIII.

9. Про схвалення Енергетичної стратегії України на період до 2035 року «Безпека, енергоефективність, конкурентоспроможність» : Розпорядження Кабінету Міністрів України від 18 серпня 2017 року № 605-р.

10. Тульчинська С. Інтелектуально-інноваційна модернізація економіки України: теоретико-методологічні аспекти : монографія. Київ : НТУУ «КПІ», 2009. 488 с.

11.Тульчинська С., Чорній Б. Диверсифікація джерел залучення інвестиційних ресурсів у підприємства розподілення електроенергії. Економічний вісник Національного технічного університету України «КПІ». 2017. Вип. 14. С. 67-74.

\section{References:}

1. Klasyfikatsiia vydiv ekonomichnoi diial'nosti (KVED - 2010), "Classification of economic activities (NACE - 2010)". URL: http://kved.ukrstat.gov.ua/KVED2010/kv10_i.html (accessed: 18 February 2019).

2. Kabinetu Ministriv Ukrainy (2000), Postanova Pro zatverdzhennia Poriadku zastosuvannia sanktsij za porushennia zakonodavstva pro elektroenerhetyku, "On Approval of the Procedure for the Application of Sanctions for Violation of the Electricity Legislation". No. 1139.

3. Kabinetu Ministriv Ukrainy (1997), Postanova Pro zatverdzhennia Pravyl okhorony elektrychnykh merezh, "On Approval of the Rules for the Protection of Electricity Networks". No. 209.

4. Zakon Ukrainy (2019) Pro Natsional'nu komisiiu, scho zdijsniuie derzhavne rehuliuvannia u sferakh enerhetyky ta komunal'nykh posluh, "On the National Commission for State Regulation in the Fields of Energy and Public Utilities”. No. 1540-VIII.

5. Kabinetu Ministriv Ukrainy (1999) Postanova Pro nevidkladni zakhody schodo stabilizatsii finansovoho stanovyscha pidpryiemstv elektroenerhetychnoi haluzi, "On urgent measures to stabilize the financial situation of the enterprises of the electric power industry". No. 441.

6. Zakony Ukrainy (2015) Pro osoblyvosti dostupu do informatsii u sferakh postachannia elektrychnoi enerhii, pryrodnoho hazu, teplopostachannia, tsentralizovanoho postachannia hariachoi vody, tsentralizovanoho pytnoho vodopostachannia ta vodovidvedennia, "On the peculiarities of access to information in the fields of electricity, natural gas, heat supply, centralized hot water supply, centralized drinking water supply and sewage". No. 887-VII.

7. Zakony Ukrainy (2000) Pro pryrodni monopolii, "On Natural Monopolies". No. 1682-III

8. Zakony Ukrainy (2019) Pro rynok elektrychnoi enerhii, "On the Electricity Market”. No. 2019-VIII.

9. Kabinetu Ministriv Ukrainy (2017) Rozporiadzhennia Pro skhvalennia Enerhetychnoi stratehii Ukrainy na period do 2035 roku "Bezpeka, enerhoefektyvnist', konkurentospromozhnist", "On approval of the Energy Strategy of Ukraine for the period up to 2035 "Security, Energy Efficiency, Competitiveness"”. No. 605-p.

10. Tul'chyns'ka, S. and Chornij, B. (2017), "Diversification of sources of attraction of investment resources in the enterprises of power distribution", Ekonomichnyj visnyk Natsional 'noho tekhnichnoho universytetu Ukrainy "KPI”, vol. 14, pp. 67-74.

11. Tul'chyns'ka, S. (2009), Intelektual'no-innovatsijna modernizatsiia ekonomiky Ukrainy: teoretyko-metodolohichni aspekty [Intellectual-innovative modernization of Ukrainian economy: theoretical and methodological aspects], NTUU "KPI", Kyiv, Ukraine. 
Biriukov Iegor

PHEI "Academician Yuriy Bugay International Scientific and Technical University”

\section{INSTITUTIONAL FUNDAMENTALS OF FUNCTIONING OF ELECTRIC POWER ENTERPRISES IN MODERN INTEGRATION REALITIES}

The article describes the institutional foundations of the operation of electric power companies in modern integration realities. It is established that according to the classification of economic activities, electricity companies belong to section D "supply of electricity, gas, steam and air conditioning". This type of economic activity includes various groups, including the group "generation, transmission and distribution of electricity". In its turn, this group of enterprises combines such classes by classification of economic activities as: electricity generation, electricity transmission, electricity distribution and electricity trading. The activities of the electricity companies are directly related and are part of the electricity system. It is substantiated that in the definitional sense the concepts are "energy economy", "unified energy system", "energy system of national economy", "energy complex", which are used in energy in the sense of systematic unity of production, transformation, transportation, transmission of different types of energy, their distribution, sales and consumption. It is found that integrating concepts is the application of energy systems theory. Functioning of electric power companies largely depends on the management of the energy system at the state level, which combines state regulation and market mechanisms, includes mechanisms of regulation of natural monopolies, tariff policy in accordance with the principles of realization of public interests. It is established that improving the functioning of the energy system is possible only if a consensus is reached between all its participants, while maintaining a balance of interests between producers and consumers of electricity. It is substantiated that the functioning of energy enterprises largely depends on the created institutional conditions for the development of the entire energy system of the state, which combines state regulation and market mechanisms, includes mechanisms for regulating natural monopolies, tariff policy in accordance with the principles of realization of public interests.

Key words: functioning, power companies, systematic approach, power system management, institutional conditions for enterprise development.

JEL classification: L94. 